\title{
FABRICATION AND EVALUATION OF HYBRID COMPONENTS OF WC/INCONEL 600 BY LIQUID STATE DIFFUSION BONDING
}

\section{GUSTAVO CASTRO-SÁNCHEZ, CHRISTIAN I. OTERO-VÁZQUEZ and JOSÉ LEMUS-RUIZ}

Instituto de Investigación en Metalurgia y Materiales

Universidad Michoacana de San Nicolás de Hidalgo

Morelia, Michoacán

México

e-mail: ruizmag@gmail.com

\begin{abstract}
The main objective of this work was to study various aspects of liquid state diffusion bonding of cylindrical samples of WC (with 6\% Co) and commercially pure super alloy Inconel 600 produced by brazing using a $25 \mu \mathrm{m}$ thick $70 \mathrm{Cu}-30 \mathrm{Zn}$ (wt\%) alloy as joining element. Joining experiments were carried out on $\mathrm{WC} / \mathrm{Cu}$ $\mathrm{Zn} /$ Inconel 600 combinations at temperature of $980^{\circ} \mathrm{C}$ and $1000^{\circ} \mathrm{C}$ using different holding times under argon (Ar) atmosphere. The results show that it is possible create a successful joint at temperature and times used and joining occurred by the formation of a diffusion zone. The joining is feasible because it presents an homogeneous interface with no several interfacial cracking and porosity. Scanning electron microscopy (SEM) micrographs show the different intermediate diffusion layers formed in the reaction zone, and the width of these layers increases with bonding temperature and time. Electron probe microanalysis (EPMA) revealed that at any particular bonding temperature, Co of the $\mathrm{WC}$, as well as $\mathrm{Ni}, \mathrm{Cr}$, and $\mathrm{Fe}$ of the Inconel 600, travels into the Cu-Zn joining elements. Some points of precipitation of $\mathrm{Cr}$ are observed in both, close the WC and the Inconel 600 of the
\end{abstract}

Keywords and phrases: WC, inconel 600, diffusion bonding, Cu-Zn alloy, sheer strength. Received March 16, 2017

(C) 2017 Scientific Advances Publishers 
interface. Joining strength was obtained by shear testing with a maximum joint strength of $44 \mathrm{MPa}$ for $\mathrm{WC} / \mathrm{Cu}-\mathrm{Zn} / \mathrm{Inconel} 600$ samples joined at $1000^{\circ} \mathrm{C}$ and 25 minutes.

\section{Introduction}

Tungsten carbide/cobalt (WC-Co) cemented carbides consist of large volume fractions of WC particles embedded in Co binder [1]. The hard WC grains and the ductile Co binder phase possess good compatibility, is one of the most important groups materials used as cutting tools, wear parts and, as replacement of standard materials for tools, dies, and machine components [2,3], owing to its unique and superior mechanical properties such as high modulus, hardness and wear resistance combined with good high temperature mechanical properties [4, 5]. In most applications, ceramic materials are used in combination with metals, and this has generated a continued interest in the use of joining technologies to produce complex configurations from assemblies of simple shapes [6]. Joining ceramics to metals is a key technology in the use of advanced ceramics in complex structures [7, 8]. Moreover, the use of advanced ceramics depends on the reliability of ceramic-metal joining processes and the properties of the resulting interfaces.

Several methods of joining ceramics to metals have been developed, among the most common ones are included (i) active metal brazing, that need an intermediate liquid phase [9] and (ii) solid-state diffusion bonding [10]. One widely-used method for joining ceramics consists of brazing with a reactive metal alloy, however, the highest obstacle of successful brazing of ceramics to metals is the fact that most conventional brazing materials, in general, do not wet ceramic surface $[11,12]$. Recently, a new functionally graded WC-Co/Ni component (FGWC) with a $\mathrm{Ni}$ layer on the joining surface was successfully fabricated, which was designed to improve the wettability of solders on the cemented carbides and relax the residual stresses of the WC-Co/steel joints [13]. Hongsheng Chen et al. [14] investigated the brazing of the 
FGWC and stainless steel with a $\mathrm{Cu}-\mathrm{Zn}$ alloy as interlayer. The relationships between the brazing parameters (brazing temperature and holding time) and the mechanical properties of the joints are discussed. The solidification processes of braze in the FGWC/steel joints are studied and the mechanism of releasing stresses in the joints is also analyzed [15]. Solid-state diffusion bonding is a process used to produce interfaces resistant to high temperature conditions [16] that lowers many problems encountered during brazing. The driving force for the formation of a ceramic-metal interface is the reduction in free energy when intimate physical contact is established between the ceramic and metal surfaces $[17,18]$ as a result of the plastic deformation of the metal. The mismatch in the CTE of the ceramic-metal joining materials can result in areas of high residual stresses at the interface during the cooling process [19] generating cracks or defects near the bonded zone. In solid-state diffusion bonding, the bonded zone should provide a strong junction between the two dissimilar materials, which means that the reaction product layer should not contain compounds that have mechanical properties significantly inferior to those of the metal and the ceramic $[8,20]$. The strength of diffusion bonded ceramics to metals depends on the nature and microstructure of the interface between the materials [21]. Therefore, in order to understand the mechanical performance of joints, it is important to understand the mechanisms of interface formation between the metal and ceramic. This research is focused on the use of brazing or liquid-state diffusion bonding technique to study the fabrication and interface characterization of WC-Co/Cu-Zn/Inconel 600 combinations joints.

\section{Materials and Methods}

The material used in this work were WC/6Co (wt\%) (Goodfellow, England), Inconel 600 supplied in rectangular plate shape, and Cu70Zn30 brass foil (Johnson Matthew, USA). The WC original rods were cut into blocks of cylindrical geometry of $3 \mathrm{~mm}$ and diameter of the supplied 
rods $(6.35 \mathrm{~mm})$, and the Inconel 600 in rectangular geometry of $1 \times 1 \mathrm{~cm}$ and thickness of the supplied plate $(3 \mathrm{~mm})$, using a diamond blade in a low-speed wafering saw, the thickness of the $\mathrm{Cu}-\mathrm{Zn}$ foil was of $0.025 \mathrm{~mm}$ $(25 \mu \mathrm{m})$. Chemical composition of the materials can be observed at Table 1 and atomic force analysis of a polished WC sample is showed in Figure 1. It can be observed the WC particulate inside the Co matrix of the cermets material.

Table 1. Chemical composition of the materials

\begin{tabular}{|c|c|c|c|c|c|c|c|c|}
\hline & $\mathrm{Ni}$ & $\mathrm{Cr}$ & $\mathrm{Fe}$ & $\mathrm{C}$ & $\mathrm{Mn}$ & $\mathrm{Si}$ & $\mathrm{Cu}$ & $\mathrm{Zn}$ \\
\hline \multicolumn{7}{|c|}{ (wt.\%) } \\
\hline Inconel 600 & 72 & $14-17$ & $6-10$ & 0.15 & 1.0 & 0.5 & 0.5 & - \\
\hline Cu-Zn & - & - & - & - & - & - & 70 & 30 \\
\hline
\end{tabular}

Dissimilar joints combinations, WC/Cu-Zn/Inconel 600, were mounted axially such that their polished surfaces were in contact. The specimens to be joined were placed in a graphite die embedded in a boron nitride (99.5\% pure) powder bed; this die consists of a screw that on turning clockwise can impart pressure to the sandwich assembly in order to prevent movements of the pieces by keeping the joints in contact.
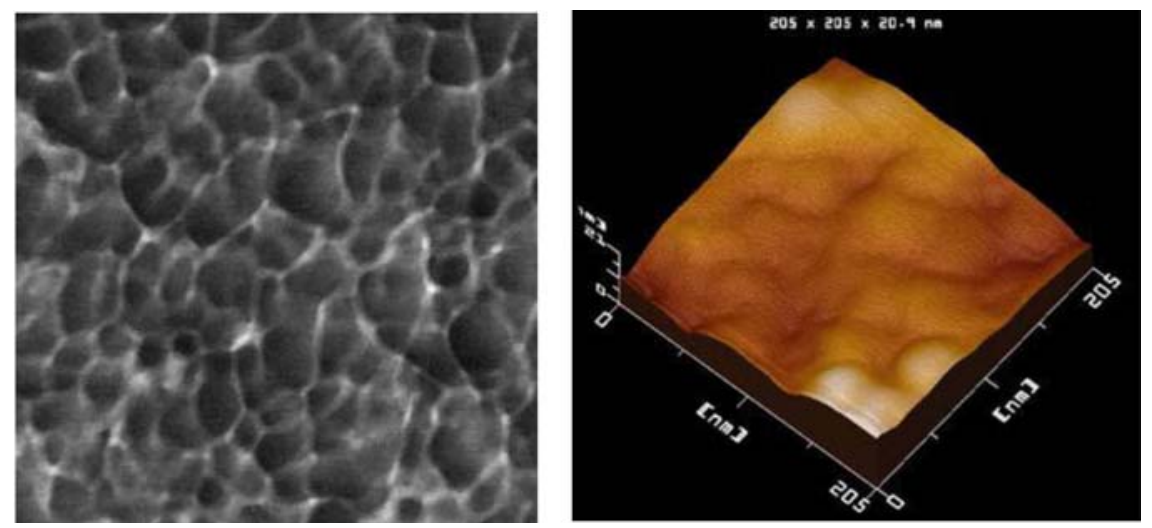

Figure 1. Atomic force microscopy analysis at WC surface sample. 
The experimental apparatus use to join the sample combinations as been describe elsewhere [22], and consists of a resistance furnace with alumina-tube chamber of $80 \mathrm{~cm}$ long and $8 \mathrm{~cm}$ in diameter. Joining experiments were carried out on $\mathrm{WC} / \mathrm{Cu}-\mathrm{Zn} / \mathrm{Inconel} 600$ combinations at temperature of $980^{\circ} \mathrm{C}$ and $1000^{\circ} \mathrm{C}$ using different holding times in Ar. Microstructural examination was performed on polished cross-sections using scanning electron microscopy and micro-analysis. The interfacial strength of $\mathrm{WC} / \mathrm{Cu}-\mathrm{Zn} / \mathrm{Inconel} 600$ joints was determined by shear test using a universal testing system with a $25 \mathrm{KN}$ load cell. For each set of experimental conditions studied, temperature and time, an average of at least three samples of $20 \mathrm{~mm}$ in length and $6.35 \mathrm{~mm}$ in diameter, were used to determine the interface strength.

\section{Results and Discussion}

The experimental results shown a successful joining achieved for both $980^{\circ} \mathrm{C}$ and $1000^{\circ} \mathrm{C}$ at the different bonding times for $\mathrm{WC} / \mathrm{Cu}-\mathrm{Zn} / \mathrm{Inconel}$ 600 combinations. Joints of WC to Inconel 600 samples are formed through the formation of a diffusion interface on the $\mathrm{Cu}-\mathrm{Zn}$ joining element as a result of diffusion of $\mathrm{Co}$ to $\mathrm{Cu}-\mathrm{Zn}$, as well as diffusion of $\mathrm{Ni}$, $\mathrm{Fe}$, and $\mathrm{Cr}$. On the other hand, liquid formation occurs during joining of $\mathrm{WC} / \mathrm{Cu}-\mathrm{Zn} / \mathrm{Inconel} 600$ (melting point of $\mathrm{Cu}-\mathrm{Zn} \cong 950^{\circ} \mathrm{C}$ ) and joining take place by liquid state diffusion and interaction of the components species with $\mathrm{Cu}$ and $\mathrm{Zn}$ of the $\mathrm{Cu}-\mathrm{Zn}$ alloy. Figure 2 shows a cross-section of the interface obtained for a sample of $\mathrm{WC} / \mathrm{Cu}-\mathrm{Zn} / \mathrm{Inconel} 600$ bonded at $980^{\circ} \mathrm{C}$ for 15 minutes. It can be seen a continuous and homogeneous diffusion interface on the metal side free of porosity and thermal cracks. 

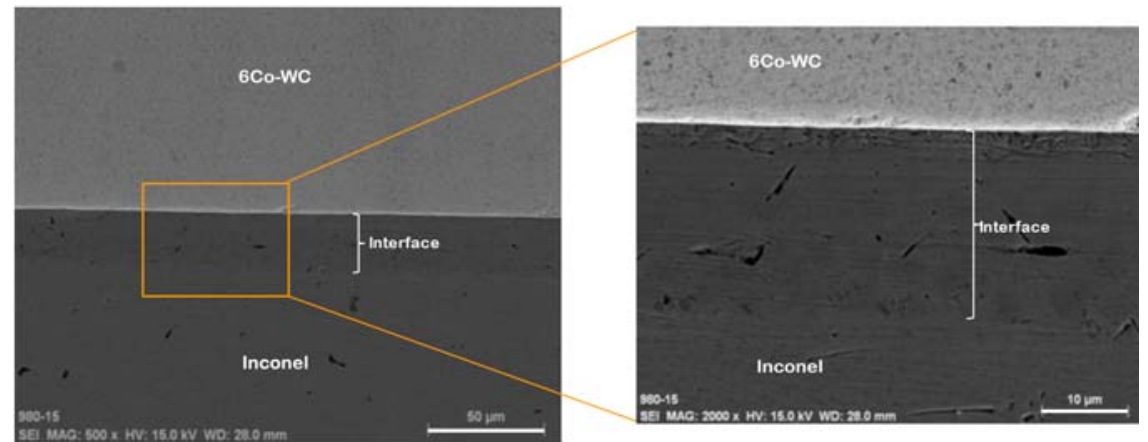

Figure 2. SEI of the cross-section interface of $\mathrm{WC} / \mathrm{Cu}-\mathrm{Zn} / \mathrm{Inconel} 600$ samples joined at $980^{\circ} \mathrm{C}$ for 15 minutes.

Electron probe micro-analysis performed on these samples are shown in Figure 3 and indicated that $\mathrm{Ni}, \mathrm{Co}, \mathrm{Cr}, \mathrm{Fe}, \mathrm{Cu}$, and $\mathrm{Zn}$ are in the diffusion interface, however no phases were detected and the components are in solution in the bonding interface. According with the thermodynamic, $\mathrm{WC}$ is stable at working temperature, therefore $\mathrm{W}$ and $\mathrm{C}$ interactions with $\mathrm{Cu}-\mathrm{Zn}$ are not expected in the joining zone. Diffusion is the dominating reaction mechanism in diffusion joining, consequently the high affinity of $\mathrm{Co}, \mathrm{Cr}, \mathrm{Fe}$, and $\mathrm{Ni}$ for $\mathrm{Cu}$ and $\mathrm{Zn}$ resulted in immediate diffusion with some modifications depending on the joining parameters, such as bonding temperature and time, because these parameters affect the concentration of diffusing of the components at the interface, and therefore, the nature of the resulting interface. 


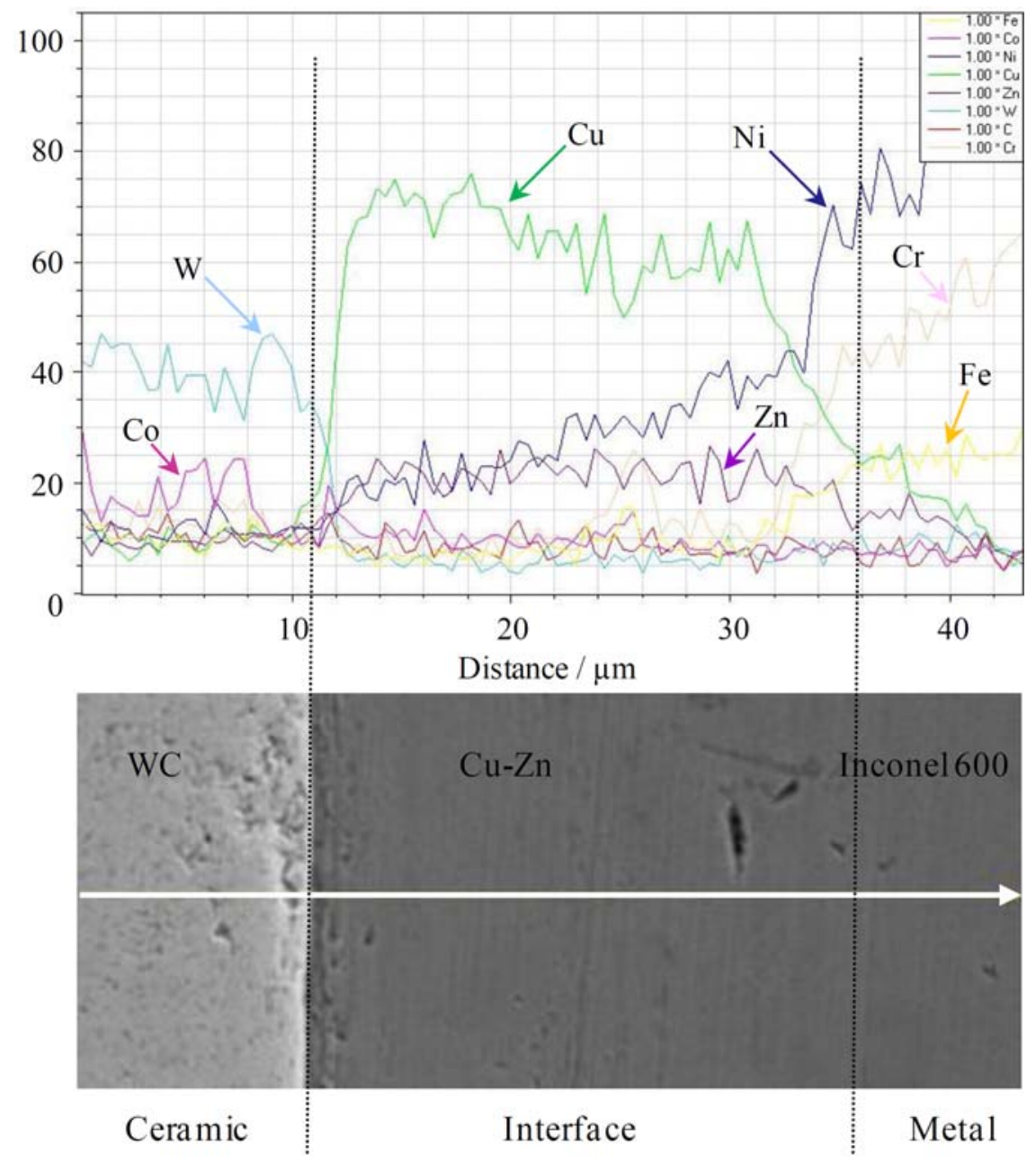

Figure 3. Electron probe line micro-analysis through the interface in a $\mathrm{WC} / \mathrm{Cu}$ - Zn/Inconel 600 sample joined at $980^{\circ} \mathrm{C}$ for 15 minutes.

Since joining of $\mathrm{WC} / \mathrm{Cu}-\mathrm{Zn} / \mathrm{Inconel} 600$ occurred at relatively high temperature and liquid formation occurred during the process, this promoted an interfacial interactions and bonding between the materials. A qualitative overview of the different components across the $\mathrm{WC} / \mathrm{Cu}$ $\mathrm{Zn/Inconel} 600$ interface was studied using atomic distributions for a sample joined at $980^{\circ} \mathrm{C}$ for 15 minutes. The results are illustrated in 
Figure 4, where the interface is aligned with the $\mathrm{WC}$ on the top and Inconel 600 on the underside. The main elements analyzed were $\mathrm{W}$, Co, $\mathrm{Cu}, \mathrm{Zn}, \mathrm{Ni}, \mathrm{Cr}$, and $\mathrm{Fe}$. The different contrast from dark to colour corresponds to the increase in the concentration of the specific element.
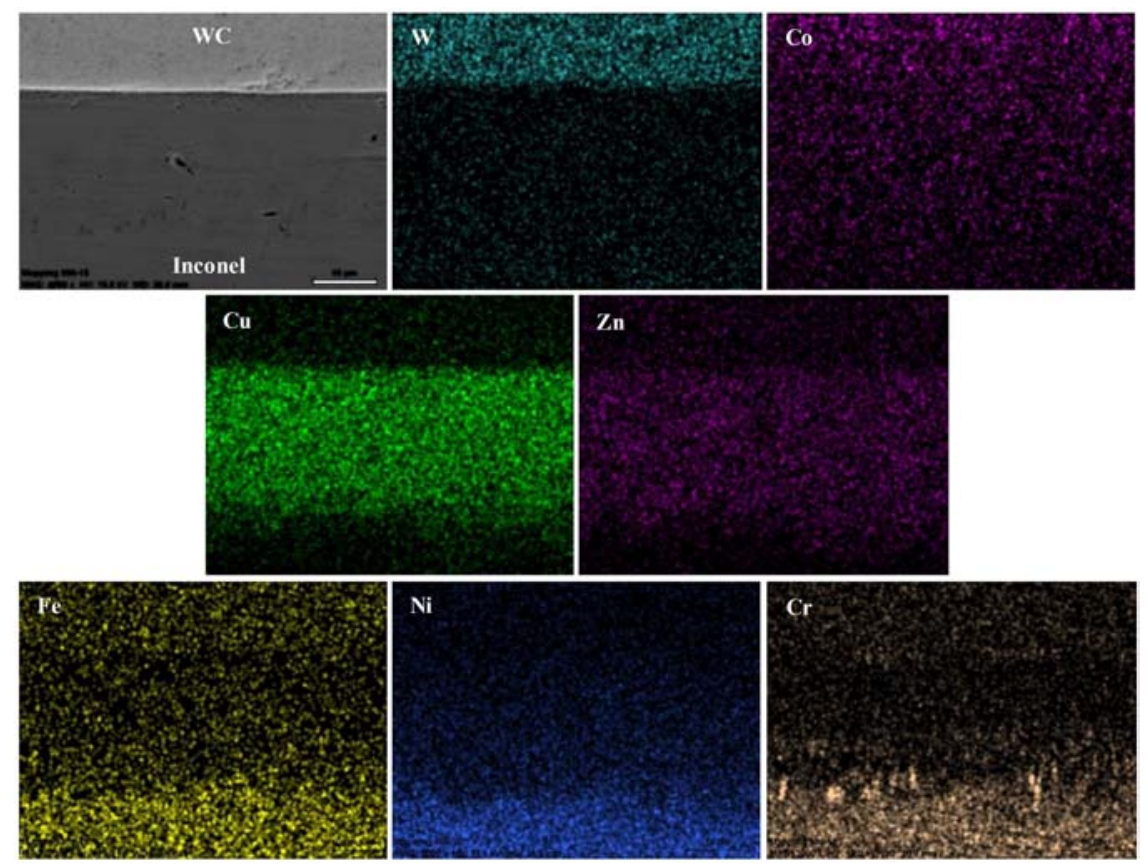

Figure 4. Mapping analysis through the interface in a WC/Cu-Zn/Inconel 600 sample joined at $980^{\circ} \mathrm{C}$ for 15 minutes.

In the Co-map, the different contrast corresponds to the decrease in concentration of Co, diffusion of Co into the interface can be observed. For the Ni, Cr, and Fe-maps, a decrease in the intensity corresponding to a decrease in the concentration of $\mathrm{Ni}, \mathrm{Cr}$, and $\mathrm{Fe}$ observed in the direction of WC, passing through the interface demarcating clearly the diffusion of these components. For the $\mathrm{Cu}$ and $\mathrm{Zn}$-maps, the concentration decreased close to the Inconel 600 interface clearly delineating the diffusion zone however evaporations of $\mathrm{Zn}$ during bonding could be occurred. No diffusion of $\mathrm{W}$ into the interface can be observed. These results confirmed that $\mathrm{Co}, \mathrm{Ni}, \mathrm{Cr}, \mathrm{Fe}$, and $\mathrm{Cu}$ were the main diffusing element into the interface. Some points of concentrations of $\mathrm{Cr}$ close to the Inconel 600 
interface are observed in the Cr-map. On the other hand, Figure 5 shows a cross-section of the interface observed in WC/Zn-Cu/Inconel 600 brazing samples produced at $1000^{\circ} \mathrm{C}$ for 35 minutes, it can be observed that increasing the bonding temperature and time, the diffusion increase forming a continuous bonding layer free of porosity. The interface was get by backscattering electron image and it is possible to observe a continuous dark layer close to the cermet WC as well as some point close to the Inconel 600 bonding line.
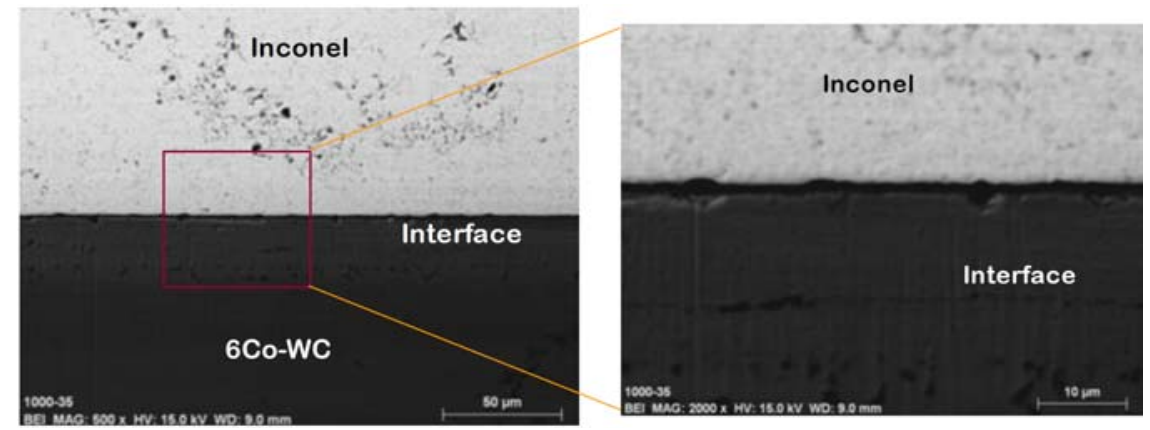

Figure 5. BEI of the cross-section interface of $\mathrm{WC} / \mathrm{Cu}-\mathrm{Zn} / \mathrm{Inconel} 600$ samples joined at $1000^{\circ} \mathrm{C}$ for 35 minutes.

Electron probe micro-analysis performed on these samples confirmed that $\mathrm{Co}, \mathrm{Cu}, \mathrm{Zn}, \mathrm{Ni}, \mathrm{Cr}$, and $\mathrm{Fe}$ were the main diffusing element into the interface. An overview of the different components in the interface was obtained in a WC/Zn-Cu/Inconel 600 sample joined at $1000^{\circ} \mathrm{C}$ for 35 minutes by line analysis using electron probe micro-analysis. The results are illustrated in Figure 6 where the WC and Inconel 600 are on the left and right, respectively. The scan line was chosen to start on the WC side of the sample through the interface, $\mathrm{Cu}-\mathrm{Zn}$, finishing on the Inconel 600 side. The $\mathrm{Ni}, \mathrm{Cr}$, and $\mathrm{Fe}$ signals reached its maximum at the Inconel- $\mathrm{Cu}$ boundary. It could be observed inter-diffusion of Inconel- $\mathrm{Cu}$ and $\mathrm{Co}-\mathrm{Cu}$ throughout the interface. It is important remark how the concentration of $\mathrm{Cr}$ increase inside the dark layer and points revealed by BEI close to the WC and Inconel 600, respectively. In the region corresponding to diffusion zone high levels of $\mathrm{Cu}$ and $\mathrm{Zn}$ were observed, however evaporations of $\mathrm{Zn}$ during bonding could be occurred, how was observed by Zhang et al. [23]. 


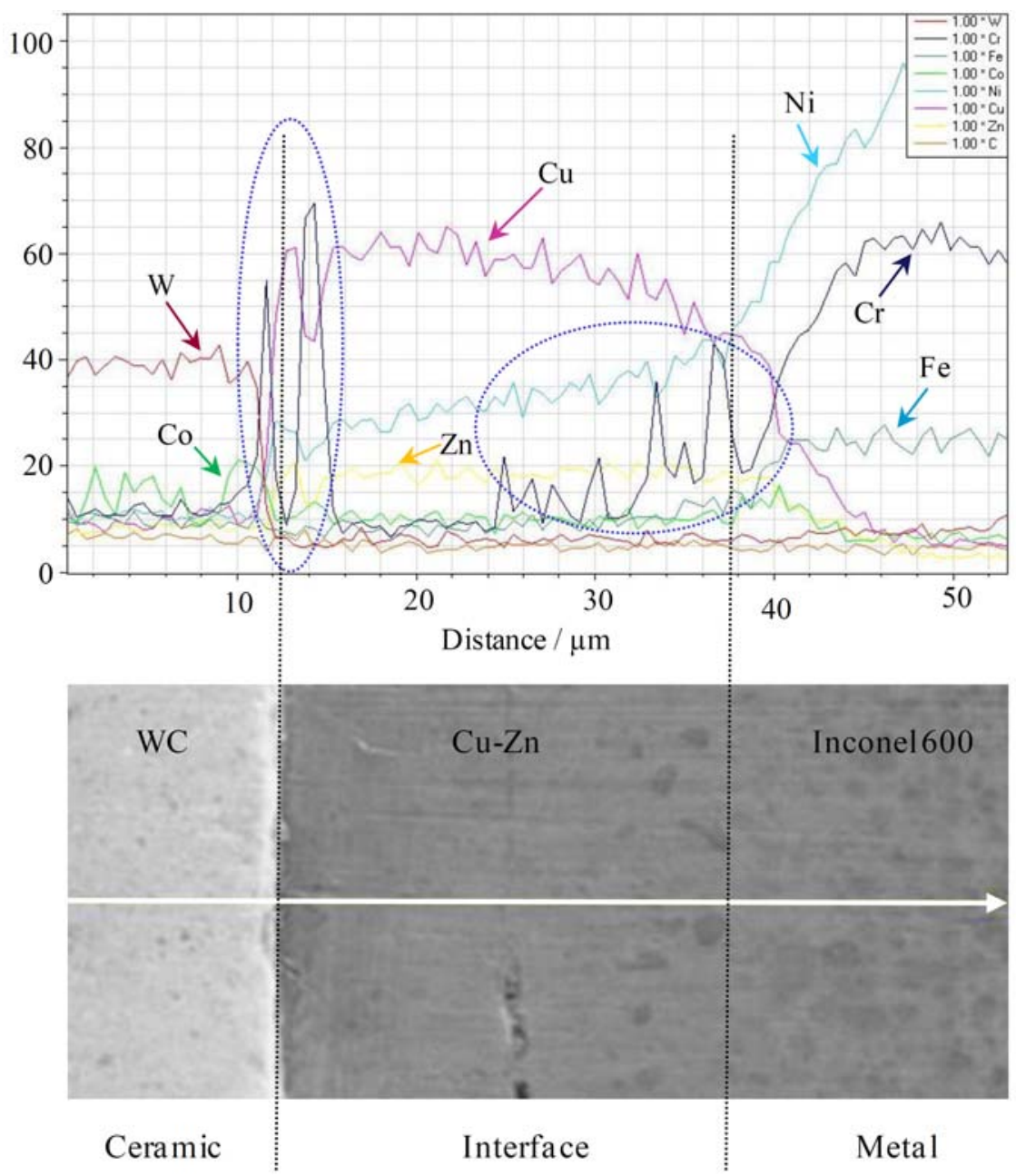

Figure 6. Line analysis through the interface in a WC/Cu-Zn/Inconel 600 sample joined at $1000^{\circ} \mathrm{C}$ for 35 minutes.

Figure 7 shows an interface of the joint produced at $1000^{\circ} \mathrm{C}$ for 35 minutes by (a) SEI, (b) a qualitative overview of Cr-map, and (c) BEI. It can be observed clearly the concentration of $\mathrm{Cr}$ in the dark layer and points inside the Inconel 600, confirming the diffusion of $\mathrm{Cr}$ during bonding process. 


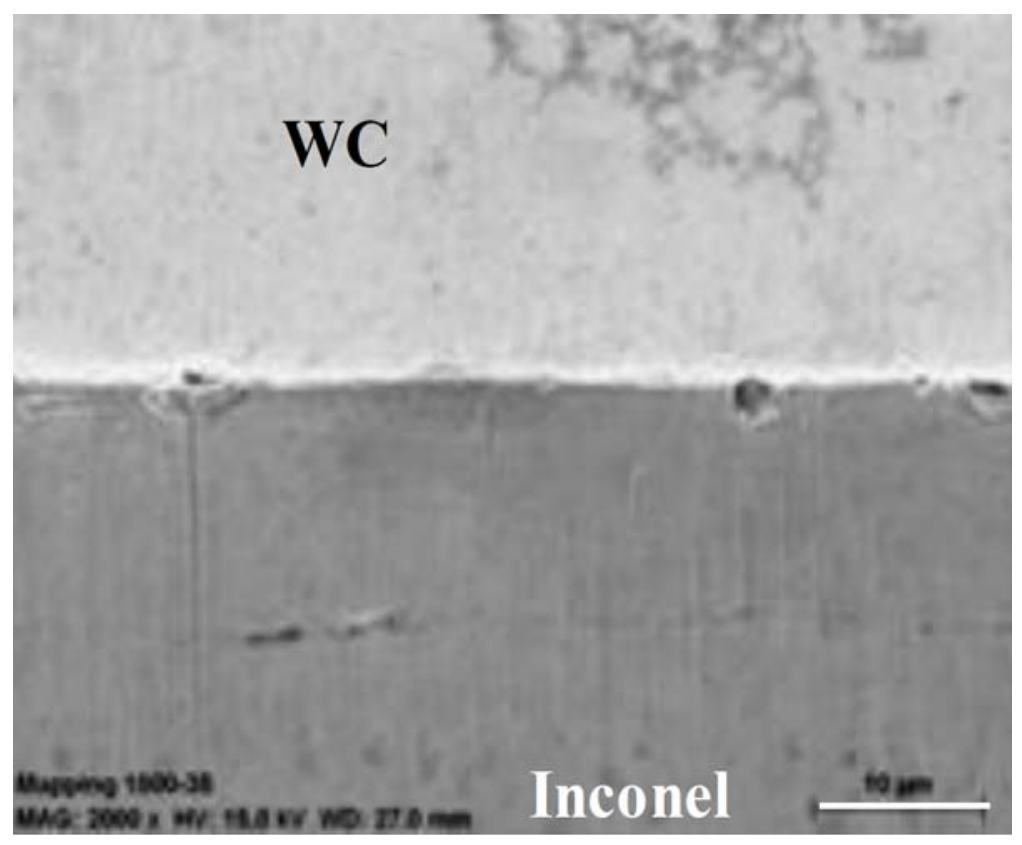

(a)

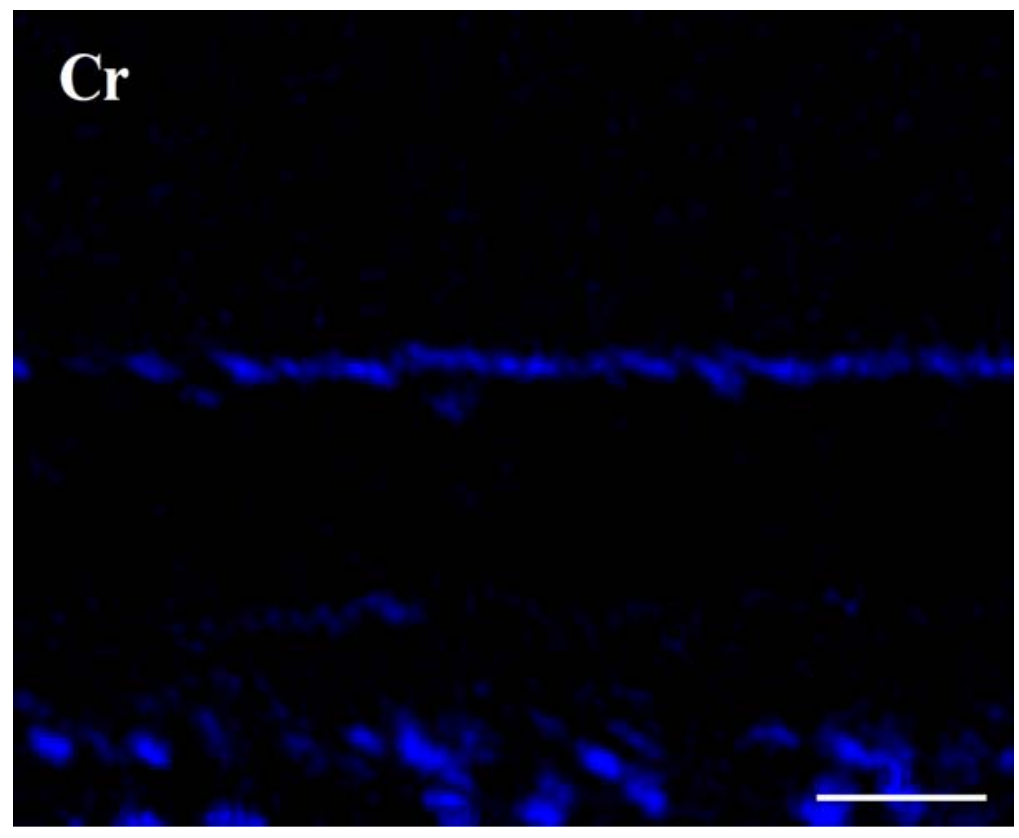

(b) 


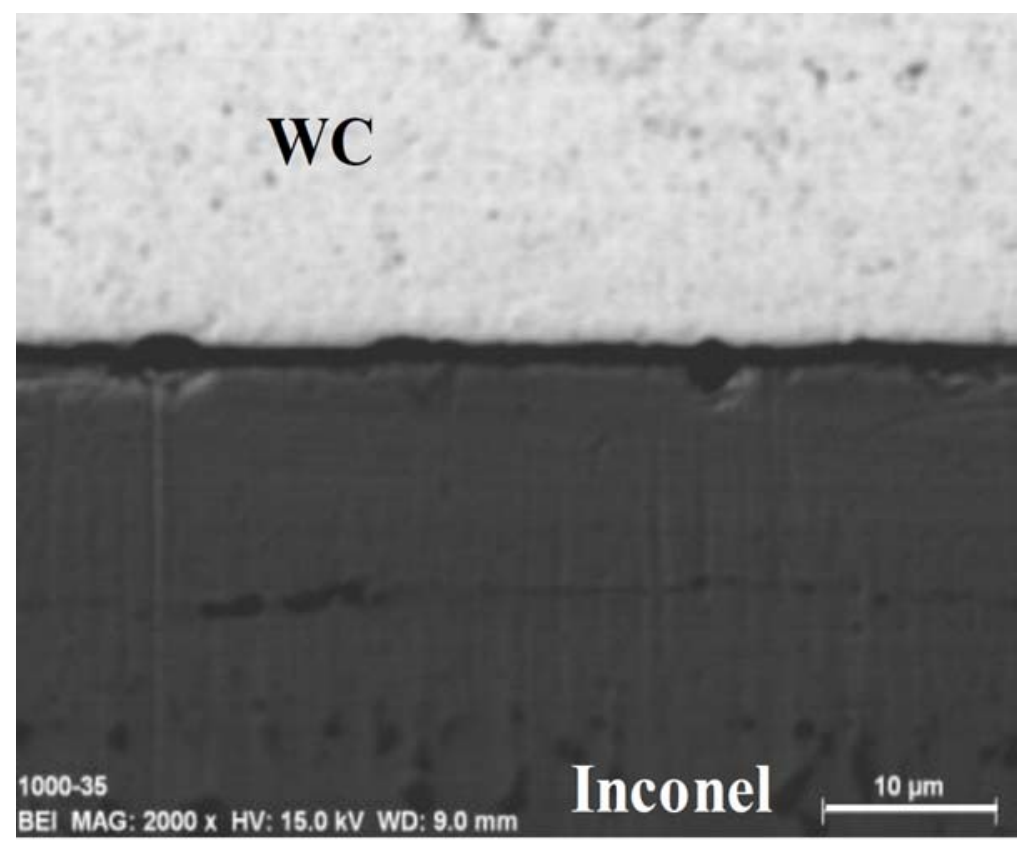

(c)

Figure 7. Cross-section of the interface in a WC/Cu-Zn/Inconel 600 sample joined at $1000^{\circ} \mathrm{C}$ for 35 minutes, (a) SEI, (b) Cr-mapping, and (c) BEI.

In order to establish a mechanical evaluation, joint strength in WC/Cu-Zn/Inconel 600 samples was measured using shear test. The shear strength was evaluated for $\mathrm{WC} / \mathrm{Cu}-\mathrm{Zn} / \mathrm{Inconel} 600$ joins produced at $1000^{\circ} \mathrm{C}$ and times of 15,25 , and 35 minutes, as well as samples joined at $980^{\circ} \mathrm{C}$ for 35 minutes. The results obtained for $\mathrm{WC} / \mathrm{Cu}-\mathrm{Zn} / \mathrm{Inconel} 600$ samples are shown in Figure 8. The error bars correspond to plus or minus the standard deviation for the average joint strength of at least three samples for each set of experimental conditions. 


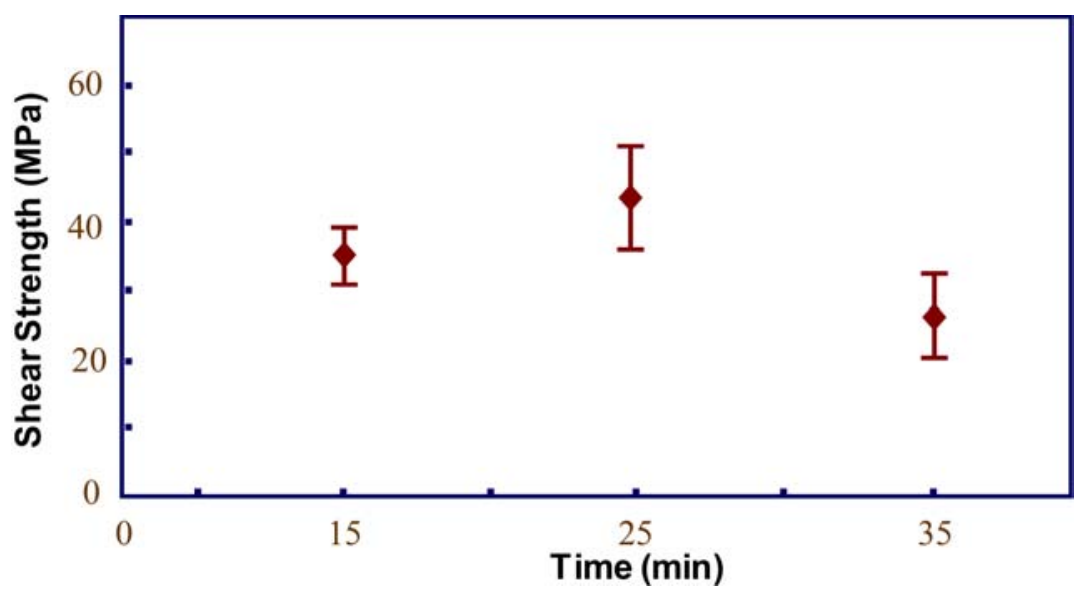

Figure 8. Shear strength in function of time for $\mathrm{WC} / \mathrm{Cu}-\mathrm{Zn} / \mathrm{Inconel} 600$ sample joined at $1000^{\circ} \mathrm{C}$.

It can be observed that the strength of the joint increased from a value of $35 \mathrm{MPa}$ and reached a maximum value of $44 \mathrm{MPa}$, when the time was increased from 15 to $25 \mathrm{~min}$, respectively, and decreased beyond this time (35 min) until a valor of $29 \mathrm{MPa}$. This improvement was attributed to the increase of interface diffusion and formation of a strong chemical bridge between the two materials. On the other hand, the thickness of the reaction zone increases with time and may dominate in the final strength.

Reaction products are generally brittle, and as the thickness of these phases increases, the joint strength, at first, rises due to the creation of a strong, integral bond and then reaches a maximum and then decreases as the interface continues to grow, as the presence of the dark layer close to WC bonding line showed in Figure 7. The effect of a reaction layer on the interface strength depends on a number of factors such as the mechanical properties of the reaction layer, its thickness and morphology. The choice of suitable conditions to prepare ceramic/metal joints requires knowledge concerning the mechanism of reaction between the materials and the evolution of the interface. Therefore, the reaction layer must be 
controlled in order to ensure good joint strength. The effect of the bonding temperature is clearly observed with the joint strength obtained for joining conditions of $980^{\circ} \mathrm{C}$ and $35 \mathrm{~min}$, with average shear strength of $8 \mathrm{MPa}$. All samples showed the same type of fracture features; fracture originated and propagated mainly along the WC/Inconel 600 diffusion zone interface. The main part of the fracture surface occurred along the Inconel 600 diffusion zone interface and probably initiated at the edge of the sample. In summary, the choice of suitable conditions to prepare ceramic/metal joints requires knowledge about the mechanism of reaction between the materials and the evolution of the interface. The maximum value of $44 \mathrm{MPa}$ for the shear strength of the joint was obtained for samples diffusion bonded at $1000^{\circ} \mathrm{C}$ for 25 minutes. This strength is of the same order as the shear strength reported for Kenevisi and Mousavi Khoie [24] to joining Ti-6Al-4V to Al7075 (30MPa) and Majid et al. [25] to joining Ti-6Al-4V to Al2024 using a Cu-Zn alloy (37MPa).

\section{Conclusion}

On the basis of the results presented in this work, it has been shown that it is possible to join cermet of tungsten carbide to Inconel 600 by brazing using a $\mathrm{Cu}-\mathrm{Zn}$ alloy as joining elements at temperatures of $980^{\circ} \mathrm{C}$ and $1000^{\circ} \mathrm{C}$ on $\mathrm{WC} / \mathrm{Cu}-\mathrm{Zn} / \mathrm{Inconel} 600$ samples combinations and time vary from 15 to 35 minutes. Joining of tungsten carbide to Inconel 600 occurred by the formation of a homogeneous diffusion interface. A maximum average joint strength of $44 \mathrm{MPa}$ was obtained for $\mathrm{WC} / \mathrm{Cu}$ $\mathrm{Zn} / \mathrm{Inconel} 600$ samples joined at $1000^{\circ} \mathrm{C}$ and 35 minutes.

\section{Acknowledgement}

The authors would like to thank to CONACYT-Mexico and Universidad Michoacana de San Nicolas de Hidalgo (UMSNH) for the financial support and facilities of this research. 


\section{References}

[1] C. Colin, L. Durant, N. Favrot, J. Besson, G. Barbier and F. Delannay, Processing of functional-gradient WC-Co cermets by powder metallurgy, International Journal of Refractory Metals and Hard Materials 12 (1993-1994), 145-152.

[2] L. J. Prakash, Application of fine grained tungsten carbide based cemented carbides, International Journal of Refractory Metals and Hard Materials 13 (1995), 257-264.

[3] A. Rajabi, M. J. Ghazali, J. Syarif and A. R. Daud, Development and application of tool wear: A review of the characterization of TiC-based cermets with different binders, Chemical Engineering Journal 255 (2014), 445-452.

[4] W. B. Lee, B. D. Kwon and S. B. Jung, Effects of $\mathrm{Cr}_{3} \mathrm{C}_{2}$ on the microstructure and mechanical properties of the brazed joints between WC-Co and carbon steel, International Journal of Refractory Metals and Hard Materials 24(3) (2006), 215-221.

[5] A. Hassan, M. Y. Wahab, M. S. Noordin, C. Hussain and S. Izman, Characteristics of electroplated nickel layer on tungsten carbide, Applied Mechanics and Materials 315 (2013), 73-77.

[6] M. G. Nicholas, Joining Processes: Introduction to Brazing and Diffusion Bonding, USA: Kluwer Academic Publishers, 1998.

[7] J. G. Flores, J. Cervantes and J. Lemus, Joining of silicon nitride to metal (Mo and Ti) using a Cu-foil interlayer, Materials Science Forum 509 (2006), 99-104.

[8] J. Lemus and R. A. L. Drew, Joining of silicon nitride with a titanium foil interlayer, Materials Science Engineering A 352-306 (2003), 169-178.

[9] C. J. H. Chen, Q. Wang and Y. Li, Effect of brazing temperature and holding time on joint properties of induction brazed WC-Co/carbon steel using Ag-based alloy, Journal of Materials Processing Technology 229 (2016), 562-569.

[10] G. Maizza, R. Cagliero, A. Lacobone, R. Montanari, A. Varone, A. Mezzic and S. Kaciulisc, Study of steel-WC interface produced by solid state capacitor discharge sinter-welding, Surface Interface Analysis (2016), 1-5.

[11] D. Janickovic, P. Sebo, P. Duhaj and P. Svec, The rapidly quenched Ag-Cu-Ti ribbons for active joining of ceramics, Materials Science Engineering A 304-306 (2001), 569-573.

[12] A. H. Carim and C. H. Mohr, Brazing of alumina with $\mathrm{Ti}_{4} \mathrm{Cu}_{2} \mathrm{O}$ and $\mathrm{Ti}_{3} \mathrm{Cu}_{3} \mathrm{O}$ interlayers, Materials Letter 33 (1997), 95-199.

[13] H. S. Chen, K. Q. Feng, J. Xiong, J. J. Luo, Z. X. Guo and H. Wang, Characterization and forming process of a functionally graded $\mathrm{WC}-\mathrm{Co} / \mathrm{Ni}$ composite, International Journal of Refractory Metals and Hard Materials 35 (2012), 306-310.

[14] H. Chen, K. Feng, J. Xiong and Z. Guo, Characterization and stress relaxation of the functionally graded WC-Co/Ni component/stainless steel joint, Journal of Alloys and Compounds 557 (2013), 18-22. 
[15] H. Chen, K. Feng, S. Wei, J. Xiong, Z. Guo and H. Wang, Microstructure and properties of WC-Co/3Cr13 joints brazed using $\mathrm{Ni}$ electroplated interlayer, International Journal of Refractory Metals and Hard Materials 33 (2012), 70-74.

[16] A. Shirzadi, Solid state diffusion bonding, in Edit. Y. N. Zhou, Microjoining and Nanojoining, Chapter 9 (2008), 234-249.

[17] L. Wang and F. Aldinger, Joining of advanced ceramics in green state, Materials Letter 54 (2002), 93-97.

[18] E. Heikimheimo, I. Isomaki, A. A. Kodentsov and F. J. J. Van Loo, Chemical interaction between $\mathrm{Fe}$ and silicon nitride ceramic, Journal of the European Ceramics Society 17 (1997), 25-31.

[19] M. R. Locatelli, B. J. Dalgleish, K. Nakashima, A. P. Tomsia and A. M. Glaeser, New approaches to joining ceramics for high-temperature applications, Ceramics International 23 (1997), 313-322.

[20] R. A. Marks, D. R. Chapman, D. T. Danielson and A. M. Glaeser, Joining of alumina via copper/niobium/copper interlayers, Acta Materialia 48 (2000), 4425-4438.

[21] A. K. Jadoon, B. Ralph and P. R. Hornsby, Metal to ceramics joining via a metallic interlayer bonding technique, Journal of Materials Processing Technology 152 (2004), 257-265.

[22] J. Lemus-Ruiz, J. A. Verduzco, J. González-Sánchez and V. H. López, Characterization, shear strength and corrosion resistance of self joining AISI 304 using a Ni-Fe-Cr-Si metallic glass foil, Journal of Materials Processing Technology 223 (2015), 16-21.

[23] J. Zhang, H. Y. Fang, Y. Zhou and M. Naka, Effect of bonding condition on microstructure and properties of the $\mathrm{Si}_{3} \mathrm{~N}_{4} / \mathrm{Si}_{3} \mathrm{~N}_{4}$ joint brazed using Cu-Zn-Ti filler alloy, Key Engineering Materials 249 (2003), 255-260.

[24] M. S. Kenevisi and S. M. Mousavi Khoie, A study on the effect of bonding time on the properties of Al7075 to Ti-6Al-4V diffusion bonded joint, Materials Letters 76 (2012), 144-146.

[25] M. Samavatian, A. Halvaee, A. A. Amadeh and A. Khodabandeh, Transient liquid phase bonding of $\mathrm{Al} 2024$ to Ti-6Al-4V alloy using $\mathrm{Cu}-\mathrm{Zn}$ interlayer, Transaction Nonferrous Metal Society China 25 (2015), 770-775. 